\title{
PEMANFAATAN DAUN PINUS JARUM UNTUK DIJADIKAN BRIKET BIOCOAL SEBAGAI ENERGI LISTRIK ALTERNATIF
}

\author{
Fitriani Said ${ }^{1}$, Herawati ${ }^{2}$ \\ ${ }^{1,2}$ Universitas Borneo Tarakan Kota Tarakan Provinsi Kalimantan Utara Indonesia \\ 1fitriani@borneo.ac.id \\ ${ }^{2}$ heirayeyy@gmail.com
}

\begin{abstract}
Biomass is organic material produced through the photosynthetic process in the form of products or waste. Examples of biomass include plants, trees, grass, agricultural waste, forest waste, feces and livestock manure. This biomass can be used as an alternative fuel to replace petroleum which is suitable for development in Tarakan. One of the abundant sources of biomass is needle pine leaves which are found on the UBT campus, Pesisir Charity Beach and Tarakan City Nursery. The selection of fallen needle pine leaves as biomass in this study was based on the absence of utilization of pine leaf waste. Thus, in this study, dry needle pine leaf waste will be utilized to make briquettes mixed with coal with a variant of adhesive composition. There are 3 types of adhesives used, sago, starch starch and clay. Of the 3 types of adhesives, each sample was tested to obtain the value of moisture content, ash content, heat and electrical energy. Briquettes can be said to be good if they have a water content value below $8 \%$ according to SNI. Where the water content in the sago adhesive is in the range of more than 6\%, while for starch adhesive it is in the range of 5\%-6\% and for clay adhesive the value is in the range of 5\%-7\%. The ash content in this study has met the SNI standard, which is below $8 \%$, but the clay adhesive has an ash content close to $8 \%$, which is $7.95 \%$. The value of voltage and current is influenced by the composition of the sample, where the smaller the percentage of the pine leaf content, the smaller it is, and vice versa. The calorific value is obtained from the analysis of existing data to obtain a large enough heating value, which is in the range of $4500 \mathrm{~J}$.
\end{abstract}

Keywords-Briquettes, Heat, Convert Heat Energy to electricity

Intisari-Biomassa adalah bahan organik yang dihasilkan melalui proses fotosintetik baik berupa produk maupun buangan. Contoh biomassa antara lain adalah tanaman, pepohonan, rumput, limbah pertanian, limbah hutan, tinja dan kotoran ternak. Biomassa ini dapat digunakan sebagai bahan bakar alternatif pengganti minyak bumi yang cocok dikembangkan di Tarakan. Salah satu sumber biomassa yang melimpah adalah daun pinus jarum banyak ditemukan di kampus UBT, Pesisir pantai amal dan Persemaian Kota Tarakan. Pemilihan daun pinus jarum yang berguguran sebagai biomassa pada penelitian ini didasarkan atas belum adanya pemanfaatan sampah daun pinus. Dengan demikian pada penelitian kali ini sampah daun pinus jarum kering akan dimanfatkan untuk dibuat menjadi briket yang di campur dengan batubara dengan varian komposisi perekat. Varian perekat yang digunakan ada 3 jenis, sagu, tepeng kanji dan tanah liat. Dari 3 jenis perekat masing-masing sampel diuji untuk mendapatkan nilai kadar air, kadar abu, kalor dan energi listrik. Briket dapat dikatakan baik jika memiliki nilai kadar air dibawah $8 \%$ menurut SNI. Dimana kadar air pada perekat sagu diantara kisaran $6 \%$ lebih, sedangkan untuk perekat kanji kisaran 5\%-6\% dan untuk perekat tanah liat mendapatkan nilai kisaran 5\%-7\%. Kadar abu pada penelitian ini sudah memenuhi standar SNI yaitu dibawah $8 \%$, tetapi pada perekat tanah liat memiliki kadar abu yang mendekati $8 \%$ yaitu sebesar $7,95 \%$. Nilai tegangan dan arus dipengaruhi oleh komposisi sampel, dimana semakin kecil persentase kadar daun pinusnya maka semakin kecil,begitu juga sebaliknya. Nilai kalor didapatkan dari hasil analisa data yang ada hingga mendapatkan nilai kalor yang cukup besar yaitu kisaran nilai $4500 \mathrm{~J}$.

Kata Kunci-Briket, Kalor, Konversi Energi Panas Ke listrik

\section{PENDAHULUAN}

Cadangan minyak bumi dan gas alam semakin berkurang dimana penambang selalu bergerak dari daratan menuju pantai hingga menuju ke dasar laut menggunakan teknologi modern dan ini terjadi secara rutin. Sementara itu permintaan minyak bumi dan gas alam semakin meningkat setiap tahunnya, hal ini yang membuat harga minyak bumi dan gas alam semakin meningkat, dimana subsidi dari pemerintah pun tidak berpengaruh besar terhadap harga yang sudah meningkat, maka dari itu masyarakat perlu melakukan pengolahan limbah yang dapat menghasilkan sumber energi alternatif sebagai pengganti bahan bakar minyak (BBM). Biomassa sangat mudah di temukan dari aktifitas pertanian, peternakan, perikanan dan limbah lainnya. Berbagai bahan biomassa yang dapat dijadikan sebagai bahan bakar bisa di ambil dari aktifitas kehutanan dan pertanian yaitu daun bambu, daun kopi dan daun pinus[9]. Biomassa adalah bahan organik yang dihasilkan melalui proses fotosintetik baik berupa produk maupun buangan [10].

Biomassa ini dapat digunakan sebagai bahan bakar alternatif pengganti minyak bumi yang cocok dikembangkan di Tarakan. Salah satu sumber biomassa yang melimpah adalah daun pinus jarum banyak ditemukan di kampus UBT, Pesisir pantai amal dan Persemaian Kota Tarakan. Pemilihan daun pinus jarum yang berguguran sebagai biomassa pada penelitian ini didasarkan atas belum adanya pemanfaatan sampah daun pinus. Dengan demikian pada penelitian kali ini sampah daun pinus jarum kering akan dimanfatkan untuk dibuat menjadi briket yang di campur dengan batubara dengan varian komposisi perekat untuk menjadi bahan bakar 
alternatif. Dalam spenelitian ini pembuatan briket biomassa menggunakan perekat dari tepung kanji, tanah liat dan tepung sagu, karena lebih mudah didapat dan harganya relatif murah. Setelah dijadikan briket kemudian akan diuji nilai kalor yang dimiliki.

Kalor adalah suatu bentuk energi yang diterima oleh suatu benda yang menyebabkan benda tersebut mengalami perubahan temperature. Seiring dengan perkembangan teknologi pada era digital dibutuhkan sumber energi listrik baru yang dapat menopang kebutuhan makhluk hidup. Salah satu energi yang belum dimanfaatkan secara optimal adalah energi kalor. Pemanfaatan energi kalor sebagai pembangkit energi listrik dapat dilakukan dengan menggunakan termoelektrik [11].

\section{LANDASAN TEORI}

\section{Tanaman Pinus}

Tanaman pinus dan cemara adalah jenis pohon yang sama sehingga termasuk dalam kategori jenis coniferous evergreen. Yang dimaksud dengan coniferous evergreen adalah jenis pohon yang tumbuh membentuk kerucut seperti topi ulang tahun dan memiliki daun berwarna hijau dalam keadaan muda sedangkan ketika saat berguguran akan berubah warna menjadi coklat. Untuk jenis pohon yang dijadikan pohon natal dalam buku dan film itu adalah jenis pohon fir atau pohon spruce. Kedua jenis pohon tersebut termasuk dalam jenis kelompok familia pinaceae, tetapi kedua pohon tersebut berasal dari genus yang berbeda, yaitu genus Cedar (pohon fir) dan genus Picea (pohon spruce).

\section{A. Habitat}

Pohon pinus atau tusam banyak ditemukan atau tumbuh secara bergerombol pada kondisi tanah tanah asam, berpasir dan kondisi tanah yang memiliki serapan air yang baik, pohon pinus juga hidup pada kawasan hutan didaerah dataran tinggi. Pohon pinus atau tusam sangat mudah beradapatasi dengan lingkungannya, bahkan terhadap perubahan cuaca sangat ekstrim. Beberapa jenis pohon pinus dapat tumbuh setelah terjadi kebakaran hutan. Untuk pohon pinus yang dewasa dapat beregenerasi dengan cepat, sedangkan jenis akar pohon pinus adalah akar tunggang dengan sistem perakaran yang dalam dan kuat sehingga cocok tumbuh di tanah dengan tekstur ringan hingga sedang.

\section{B. Morfologi Tanaman Pinus \\ 1) Akar}

Akar pada tanaman pinus merupakan akar radix primaria (tunggang) tapi juga bercabang-cabang. Struktur akar tanaman pinus sangat kuat, mencengkeram tanah, dan berwarna cokelat. Memiliki akar lembaga yang akan terus tumbuh menjadi akar pokok yang bercabang-cabang dan menjadi akar-akar yang lebih kecil. Hal ini menyebabkan daerah perakaran menjadi luas dan jangkauan penyerapan air, unsur hara juga semakin luas.

\section{2) Batang}

Tanaman pinus memiliki batang kayu yang sangat keras. Pohon pinus ini jika dilihat dari kejauhan akan tampak seperti berbentuk kerucut atau lima segitiga yang memanjang, ini dikarena batang pohon pinus ini memiliki bagian bawah yang besar dan semakin ke atas sampai puncaknya mengecil. Bentuk batang pohon pinus ini membulat dan memiliki ujung pohon muda menyerupai piramida, namun ketika sudah tua menjadi lebih melebar dan rata. Arah tumbuh pohon pinus erectus yaitu tegak lurus ke atas. Permukaan batang pohon pinus sangat kasar karena kondisinya retak - retak dan permukaan batang berwarna kecoklatan.

\section{3) Daun}

Daun pada tanaman pinus termasuk ke dalam daun majemuk. Pada daun pinus ini tidak ada bagian terlebar, karena pangkal dan ujung hampir sama ukurannya. Sedangkan panjang daun sekitar $10-20 \mathrm{~cm}$. Daun pinus memiliki ujung daun berbentuk meruncing, memiliki pangkal daun berbentuk rompang/ rata dengan diselubungi sisik berupa selaput tipis, dan juga memiliki tepi daun berbentuk rata, serta ranting daun berukuran pendek dan berbentuk seperti jarum.

\section{4) Bunga}

Bunga pada tanaman pinus termasuk ke dalam bunga berkelamin tunggal atau unisexualis. Pinus memiliki bunga yang terbagi menjadi dua, yaitu bunga jantan dan bunga betina. Untuk bunga jantan memiliki bentuk silindris dengan ukuran panjang sekitar $2 \mathrm{~cm}$ sampai 4 $\mathrm{cm}$. Sedangkan bunga betina itu sendiri memiliki bentuk kerucut, ujungnya berbentuk runcing, memiliki kulit bersisik, berwarna cokelat, dan memiliki biji dimana setiap bakal biji terdapat sayap. Bunga pinus ini pada umumnya berwarna kuning ketika bunga ini masih dalam keadaan muda dan berwarna kecoklatan ketika sudah tua.

\section{5) Buah}

Tanaman pinus memiliki buah yang berbentuk kerucut dan ada juga berbentuk silindir, tapi yang sering ditemui yaitu berbentuk silinder. Bentuknya buah pinus yang kerucut seperti pohon natal tapi kecil. Buah pinus mempunyai ukuran panjang buah sekitar 5-10 cm dan lebar buah pinus sekitar $2-4 \mathrm{~cm}$. Buah pinus ini yang sering ditemui pada umunya berwarna cokelat dan termasuk buah semua yang tidak dapat dimakan.

\section{6) Biji}

Tanaman pinus memiliki biji berbentuk pipih dan bulat telur (oval), pada bagian biji ini dilengkapi dengan sayap yang dihasilkan pada setiap dasar bunga (recetaculum) atau dari sisik buah. Pada setiap sisik buah menghasilkan dua biji, dan warna biji Pinus umumnya putih kekuningan.

\section{Batu Bara}

Batu bara merupakan benda yang berasal dari tumbuhan yang telah mati dan tertimbun dalam cekungan atau lubang yang berisi air dalam waktu sangat lama, hingga mencapai usia jutaan tahun. Hal ini yang menjadi perbedaan antara batubara dengan minyak bumi, karena minyak bumi berasal dari sumber hewani. Banyak faktor yang mempengaruhi dalam proses pembentukan batubara, yaitu besarnya temperatur dan tekanan terhadap tumbuhan mati akan mempengaruhi kondisi lapisan batubara yang terbentuk, termasuk pengayaan kandungan karbon di dalam batubara. Dalam usaha mempermudah pengenalan jenis batubara terbagi menjadi beberapa jenis diantara:

\section{a. Batubara jenis anthracite}

Batubara jenis anthracite menunjukkan ciri-ciri yaitu memperlihatkan struktur kompak, memiliki berat jenis tinggi, berwarna hitam metalik, kandungan bahan mudah 
menguap rendah, kandungan abu dan kandungan air rendah, dan mudah dipecah.

\section{b. Batubara jenis bituminous/subbituminous}

Batubara jenis bituminous/subbituminous menunjukkan ciri-ciri yaitu berwarna hitam agak kompak, kandungan karbon relatif tinggi, kandungan sulfur relatif rendah, kandungan abu dan kandungan air relatif rendah.

\section{c. Batubara jenis lignite}

Batubara jenis lignite menunjukkan ciri-ciri yaitu berwarna hitam, sangat rapuh, kandungan karbon relatif rendah, kandungan sulfur tinggi, kandungan abu relatif tinggi, dan nilai kalor rendah.

\section{Briket}

Briket merupakan bahan bakar karbon yang dibentuk melalui proses densifikasi yang diproduksi dari limbah bahan organik (biomassa) dan atau batubara yang masih mengandung sejumlah energi panas. Briket merupakan bahan bakar padat dengan dimensi tertentu yang seragam, diperoleh dari hasil densifikasi (pengempaan) bahan berbentuk curah atau serbuk, berukuran relatif kecil atau tidak beraturan sehingga sulit digunakan sebagai bahan bakar dalam bentuk. Briket merupakan bahan bakar padat yang dapat dibuat dari biomassa dan atau batubara yang mengandung karbon dengan nilai kalor cukup tinggi dan dapat menyala dalam waktu yang lama.

Untuk menghasilkan briket yang baik syaratnya adalah permukaan briket yang halus dan tidak meninggalkan bekas hitam ditangan ketika memegangnya. Selain itu briket sebagai bahan bakar ini juga harus memenuhi beberapa syarat atau kiteria, berikut adalah kiteria yang dimaksud:

a. Mudah dinyalakan.

b. Tidak mengeluarkan asap.

c. Emisi gas hasil pembakaran tidak mengandung racun

d. Kedap air dan hasil pembakaran tidak berjamur bila disimpan pada waktu lama.

e. Menunjukkan upaya laju pembakaran (waktu, laju pembakaran dan suhu pembakaran) yang baik.

Briket batubara memiliki keungggulan sebagai berikut:

a. Murah

b. Panas yang tinggi dan kontinu sehingga sangat baik untk pembakaran yang lama

c. Tidak beresiko meledak atau terbakar

d. Tidak mengeluarkan suara bising serta tidak berjelaga, dan sumber batubara berlimpah.

Dalam proses untuk menghasilkan briket yang baik dan aman, maka briket harus memenuhi beberapa syarat diatas, briket harus diuji kelayakannya. Berikut adalah beberapa hal yang perlu diperhatikan atau yang akan diuji:

\section{Kadar air}

Kadar air yang terkandung dalam produk dinyatakan sebagai kadar air. Kadar air bahan bakar padat ialah perbandingan berat air yang terkandung dalam bahan bakar padat dengan berat kering bahan bakar padat tersebut. Semakin besar kadar air yang terdapat pada bahan bakar padat maka nilai kalornya semakin kecil, begitu juga sebaliknya [10]. Kadar air dihitung dengan menggunakan persamaan [1]:

$$
\% \text { Kadar air }=\frac{a-b}{a} x 100 \%
$$

Dengan:

a = sampel briket $(\mathrm{g})$

b = sampel briket setelah di oven $(\mathrm{g})$

2. Kadar abu

Setiap briket yang dihasilkan mempunyai kandungan zat anorganik yang dapat ditentukan komposisinya sebagai berat yang tinggal ketika briket dibakar secara sempurna, zat yang yang tinggal itu biasa disebut dengan abu. Abu berasal dari lempung, pasir dan berbagai macam zat mineral lainnya. Dalam menentukan kadar abu maka persamaan rumus yang digunakan adalah sebagai berikut:

$$
\% \text { kadar abu }=\frac{\text { berat abs }}{\text { berat ampal: }} \times 100 \% \text { ) }
$$

Briket dihasilkan dari proses pirolisis, yaitu suatu proses thermal dengan kondisi sedikit atau tanpa adanya oksigen. Untuk memenuhi standar kualitas, briket yang dihasilkan tetap harus dibandingkan dengan SNI 01-62352000, dimana kualitasnya dilihatdari beberapa parameter sebagai berikut :

1. Kadar air maksimal $8 \%$

2. Kadar abu maksimal $8 \%$

Untuk menghasilkan briket yang baik maka harus memenuhi dua parameter diatas. Dari parameter tersebut akan menghasil nilai kalor yang baik karena saling mempengaruhi [5].

\section{Perekat}

Dalam produksi briket ada dua macam perekat yang biasa digunakan yaitu perekat organik dan perekat anorgannik. Bahan pencampur pada pembuatan briket yang dapat merembes kedalam permukaan cara terabsorpsi sebagian ke dalam poripori atau celah yang ada, antara lain seperti pati (sagu dan tapioka), dekstrin, tepung beras, tar, dan molasses merupakan pengertian dari bahan organik. Sedangkan bahan perekat anorganik ialah bahan pencampur pada pembuatan briket yang berfungsi sebagai perekat antar permukaan partikelpartikel penyusun briket yang tidak reaktif (inert) dan berfungsi sebagai stabilizer selama pembakaran, antara lain seperti tanah liat [3].

\section{Konversi Energi Panas Menjadi Energi Listrik}

Energi yang paling mudah untuk dikonversikan ke beberapa bentuk energi adalah energi listrik. Selain itu energi listrik dapat dihasilkan langsung dari berbagai bentuk energi tanpa harus melewati bentuk perantara energi lainnya. Maka dari itulah energi listrik sering disebut sebagai direct energi converter. Terdapat banyak aplikasi konversi yang dapat dilakukan untuk memproduksi energi listrik, seperti; konversi energi termal menjadi energi listrik, proses konversi energi sperti ini biasanya menggunakan konsep Seebeck dengan memanfaatkan termoelektrik [6].

$$
P=V x I
$$

Dengan:

$P=$ daya ( Watt)

$V=$ Tegangan $($ Volt $)$

$I=$ Arus (Ampere) 


\section{Kalor}

Nilai kalor adalah besarnya panas yang diperoleh dari pembakaran suatu jumlah tertentu bahan bakar didalam zat asam, makin tinggi berat jenis bahan bakar, makin tinggi nilai kalor yang diperoleh [10]. Kalor ialah salah satu bentuk energi yang dapat berpindah dari suatu benda ke benda yang lain. Kalor bisa diberikan pada suatu benda dengan menggunakan cara pemanasan dan sebagai salah satu dampaknya yaitu kenaikan suhu benda tersebut. Kalor bisa diambil dari benda dengan cara pendinginan dan sebagai salah satu dampaknya yakni penurunan suhu benda tersebut. Kapasitas kalor ialah jumlah kalor yang diserap oleh benda bermassa tertentu untuk menaikkan suhu sebesar $1{ }^{0} \mathrm{C}$. Satuan kapasitas kalor dalam sistem international adalah $\mathrm{J} / \mathrm{K}$. Perpindahan kalor juga bisa dihitung besarannya, bisa menggunakan rumus di bawah ini :

$$
Q=m . c . \Delta T
$$

Dengan:

$\mathrm{Q}=$ banyak kalor yang diterima ataupun dilepas oleh suatu benda ( $\mathrm{J}$ )

$\mathrm{m}$ = massa benda yang menerima ataupun melepas kalor ( $\mathrm{kg}$ )

$\mathrm{c}=$ kalor jenis zat $\left(\mathrm{J} / \mathrm{kg}{ }^{0} \mathrm{C}\right)$

$\Delta \mathrm{T}=$ perubahan suhu $\left({ }^{0} \mathrm{C}\right)$

\section{Hubungan kalor dengan listrik}

Kalor merupakan bentuk energi maka dapat berubah dari satu bentuk kebentuk yang lain. Berdasarkan Hukum Kekekalan Energi maka energi listrik dapat berubah menjadi energi kalor dan juga sebaliknya energi kalor dapat berubah menjadi energi listrik. Dalam pembahasan ini hanya akan diulas tentang hubungan energi listrik dengan energi kalor. Besarnya energi listrik yang diubah atau diserap sama dengan besar kalor yang dihasilkan. Sehingga secara matematis dapat dirumuskan.

$$
W=Q
$$

Untuk menghitung energi listrik digunakan persamaan sebagai berikut :

$$
W=P . t
$$

Bila rumus kalor yang digunakan adalah

$$
\mathrm{Q}=\mathrm{m} \cdot \mathrm{c} \cdot(\mathrm{t} 2-\mathrm{t} 1)
$$

maka diperoleh persamaan ;

$$
P . t=m . c .(t 2-t 1)
$$

\section{Heatsink}

Material yang dapat menyerap dan mendisipasi panas untuk memperluas proses transfer panas dari suatu tempat yang bersentuhan dengan sumber panas dan membuangnya merupakan pengertian dari heatsink. Bagian penting dari sebuah sistem termoelektrik generator adalah alat penukar panas atau heat exchanger, seperti heatsink dan heatpipe. Heatsink dan heatpipe merupakan bagian yang mutlak diperlukan, karena jika pada bagian sisi panas peltier dapat dipertahankan konstan, maka pada bagian sisi dingin dari elemen peltier akan mampu menyerap panas secara konstan pula.

\section{METODE PENELITIAN}

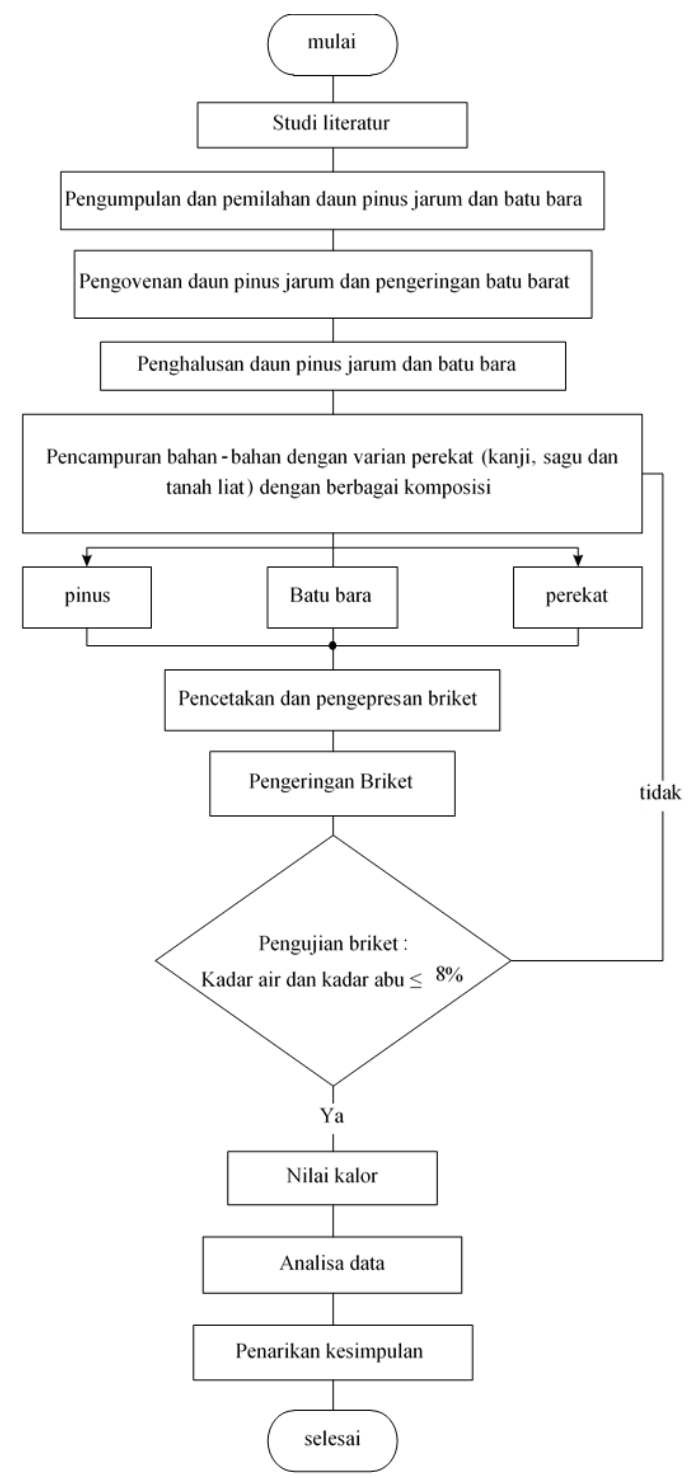

IV. HASIL DAN PEMBAHASAN

\section{A. Pengujian kadar air}

Perbandingan berat kadar air yang terkandung dalam briket kering dengan berat briket setelah dioven adalah pengertian dari kadar air briket. Semakin kecil niali kadar air maka semakin bagus nilai kalornya, dimana kadar air briket sangat berpengaruh terhadap nilai kalor. Pengujian kadar air dilakukan sebanyak 9 (sembilan) kali penganalisaan, karena ada 9 sampel yang akan di uji.

$$
\% \text { Kadar } \quad \frac{48-45}{48} \text { air }=x 100 \%=6,25 \%
$$

Sehingga yang dari analisa kadar air diatas maka akan didapatkan data hasil analisa sebagai berikut: 
Tabel 1

Hasil analisa kadar air

\begin{tabular}{|c|c|c|c|}
\hline \multirow{2}{*}{ Jenis konsentrasi } & \multicolumn{3}{|c|}{$\begin{array}{c}\text { Kadar } \\
\text { air }\end{array}$} \\
\cline { 2 - 4 } & Sagu & Kanji & $\begin{array}{c}\text { Tanah } \\
\text { liat }\end{array}$ \\
\hline $\begin{array}{c}\text { Pinus 70\% dan batu } \\
\text { bara 30\% }\end{array}$ & $6.25 \%$ & $5.56 \%$ & $7.14 \%$ \\
\hline $\begin{array}{c}\text { Pinus 50\% dan batu } \\
\text { bara 50\% }\end{array}$ & $6.12 \%$ & $6 \%$ & $6.95 \%$ \\
\hline $\begin{array}{c}\text { Pinus 30\% dan batu } \\
\text { bara 70\% }\end{array}$ & $6.38 \%$ & $6.12 \%$ & $5.10 \%$ \\
\hline
\end{tabular}

Dari data diatas dapat disimpulkan bahwa kadar air yang dimiliki briket sudah memenuhi standar SNI yaitu di bawah $8 \%$. Dimana kadar air pada perekat sagu diantara kisaran $6 \%$ lebih, sedangkan untuk perekat kanji kisaran $5 \%-6 \%$ dan untuk perekat tanah liat mendapatkan nilai kisaran 5\%-7\%. Nilai kadar air ini sangat mempengaruhi untuk nilai kadar abu dan kalor yang dihasilkan. Semakin kecil nilai kadar airnya maka akan mempermudah briket untuk terbakar dan membuat briket semakin ringan.

\section{B. Pengujian Kadar Abu}

Abu merupakan bagian yang tersisa dari hasil pembakaran dalam hal ini adalah sisa pembakaran briket. Pengaruhnya kadar abu kurang baik terhadap nilai kalor briket yang dihasilkan. Kandungan kadar abu yang tinggi dapat menurunkan nilai kalor briket arang sehingga kualitas briket arang tersebut menurun. Kadar abu adalah jumlah sisa anorganik yang dihasilkan dari pengabuan/pemijaran suatu produk.

$$
\% \text { Kadar abu }=\frac{3}{48} \quad x 100 \%=6,25 \%
$$

Tabel 2

Hasil analisa kadar abu

\begin{tabular}{|c|c|c|c|}
\hline \multirow{2}{*}{ Jenis konsentrasi } & \multicolumn{3}{|c|}{ Kadar abu } \\
\cline { 2 - 4 } & Sagu & kanji & Tanah liat \\
\hline $\begin{array}{c}\text { Pinus 70\% dan } \\
\text { batu bara 30\% }\end{array}$ & $6,25 \%$ & $7,4 \%$ & $7,1 \%$ \\
\hline $\begin{array}{c}\text { Pinus 50\% dan } \\
\text { batu bara 50\% }\end{array}$ & $6,7 \%$ & $7 \%$ & $7,3 \%$ \\
\hline $\begin{array}{c}\text { Pinus 30\% dan } \\
\text { batu bara 70\% }\end{array}$ & $6,38 \%$ & $6,7 \%$ & $7,95 \%$ \\
\hline
\end{tabular}

Dari data di atas dapat disimpulkan bahwa nilai kadar abu tidak boleh lebih besar dari nilai standar SNI yang ditetapkan. Briket dapat dikatakan baik jika nilai kadar abu lebih kecil dari nilai standarnya yaitu 8\%. Dari analisa nilai kadar abu dapat disimpulkan bahwa kadar abu yang dimiliki tiap masing-masing perekat berbeda. Kadar abu yang tinggi dapat menurunkan nilai kalor briket. Pada pengujian ini memperhitungkan berat abu yang dihasilkan oleh setiap briket. Untuk dimensi yang dihasilkan hanya satu cawan dengan ukuran 1 sendok teh.

\section{Pengaruh Suhu Dengan Tegangan}

Pada bagian pengukuran suhu ini dilakukan saat mengukur keluaran termoelektrik bertujuan agar mengetahui nilai tegangan dengan suhunya. Pengambilan data melakukan validasi data, validasi data merupakan cara mengetahui data hasil penelitian yang didapat adalah data yang sudah valid dan asli sesuai data sheet alat yang digunakan. Pada penelitian ini akan menggunakan Microsoft Exel untuk mendapatkan grafik linieritas dari alat ukur termoelektrik.

Tabel 3

Pengaruh suhu dengan tegangan

\begin{tabular}{|c|c|c|c|c|c|c|}
\hline \multirow[b]{2}{*}{$\begin{array}{l}\text { Jenis } \\
\text { Konsentras }\end{array}$} & \multicolumn{2}{|l|}{ Sagt } & \multicolumn{2}{|l|}{ Kanji } & \multicolumn{2}{|c|}{ TanahLiat } \\
\hline & $\begin{array}{l}\text { Th } \\
\text { ("C) }\end{array}$ & $\begin{array}{l}\mathrm{V} \\
(\mathrm{v})\end{array}$ & $\begin{array}{l}\text { Th } \\
\text { ("C) }\end{array}$ & $\begin{array}{l}\mathrm{V} \\
(\mathrm{v})\end{array}$ & $\begin{array}{l}\text { Th } \\
\text { ("C) }\end{array}$ & $\begin{array}{l}\mathrm{V} \\
\text { (v) }\end{array}$ \\
\hline $\begin{array}{l}\text { Pinus } 70 \% \\
\text { dan bath } \\
\text { bara } 30 \%\end{array}$ & 1223 & 5.14 & 1169 & 5.04 & 69.2 & 4.21 \\
\hline $\begin{array}{l}\text { Pinus } 50 \% \\
\text { dan baht } \\
\text { bara } 50 \%\end{array}$ & 1328 & 5.32 & 125 & 5.19 & 70 & 4.23 \\
\hline $\begin{array}{l}\text { Pitaus } 30 \% \\
\text { dar batat } \\
\text { bara } 70 \%\end{array}$ & 133.1 & 5.33 & 1328 & 5.32 & 79.6 & 4.39 \\
\hline
\end{tabular}

\section{Analisa Nilai Kalor}

Kualitasnya sebuah briket dapat ditentukan dengan nilai kalor, semakin tinggi nilai kalor briket, maka semakin baik dan bagus kualitas briket yang akan dihasilkan. Pada penelitian ini pengujian nilai kalornya dengan cara menggunakan termoelektrik, dimana keluaran dari termoelektrik berupa energi listrik.

$$
\begin{aligned}
Q & =0,048 \mathrm{~kg} \times 900 \mathrm{~J} / \mathrm{kg}^{0} \mathrm{C} \times(122,3-31){ }^{0} \mathrm{C} \\
& =3944,16 \mathrm{~J}
\end{aligned}
$$

Tabel 4

Analisa nilai kalor

\begin{tabular}{|l|c|c|c|}
\hline \multirow{2}{*}{ Jenis konsentrasi } & \multicolumn{3}{|c|}{ Nilai Kalor } \\
\cline { 2 - 4 } & Sagu & kanii & Tanah liat \\
\hline $\begin{array}{l}\text { Pinus } 70 \% \text { dant } \\
\text { batu bara 30\% }\end{array}$ & $3944.16 \mathrm{~J}$ & $4189.32 \mathrm{~J}$ & $3457.44 \mathrm{~J}$ \\
\hline $\begin{array}{l}\text { Pinus } 50 \% \text { dant } \\
\text { batu bara 50\% }\end{array}$ & $4533.48 \mathrm{~J}$ & $4230 \mathrm{~J}$ & $4140 \mathrm{~J}$ \\
\hline $\begin{array}{l}\text { Pinus 30\% dant } \\
\text { batu bara 70\% }\end{array}$ & $4339.98 \mathrm{~J}$ & $4507.02 \mathrm{~J}$ & $4286.52 \mathrm{~J}$ \\
\hline
\end{tabular}

\section{E. Hubungan Antara Kalor dengan Listrik}

Berdasarkan maka hasil analisis dan pembahasan yang telah diuraikan diatas, dapat disimpulkan bahwa komposisi tiap sampel berpengaruh terhadap besar kalor, perbedaan komposisi dan jenis perekat akan menyebabkan perbedaan kalor yang dihasilkan untuk sumber energi listrik yang sama. Hubungan antara kalor ke listrik ialah, dapat mengkonversikan nilai kalor ke listrik dengan persamaan $W=Q$.

$$
\begin{aligned}
& P=V . I \\
& P=5,14 \text { x } 0,514 \\
& P=2,64196 \text { watt }
\end{aligned}
$$


Tabel 5

Hubungan antara kalor dengan daya

\begin{tabular}{|c|c|c|c|c|c|c|}
\hline \multirow{2}{*}{ Jenis Kansentras } & \multicolumn{2}{|c|}{ Sagu } & \multicolumn{2}{c|}{ Kanji } & \multicolumn{2}{c|}{ TanahLiat } \\
\cline { 2 - 7 } & $P$ & $t(j)$ & $P$ & $t(j)$ & $P$ & $t(j)$ \\
\hline $\begin{array}{l}\text { Pinus 70\% dan } \\
\text { batud bara 30\% }\end{array}$ & 2,64196 & 0.24 .58 & 2,54016 & 0.27 .25 & 1,77241 & 0.32 .47 \\
\hline $\begin{array}{l}\text { Pinus 50\% dan } \\
\text { batud bara 50\% }\end{array}$ & 2,83024 & 0.26 .6 & 2,69361 & 0.26 .3 & 1,78929 & 0.38 .32 \\
\hline $\begin{array}{l}\text { Pinus 30\% dan } \\
\text { batu bara 70\% }\end{array}$ & 2,84089 & 0.25 .31 & 2,83024 & 0.26 .32 & 1,92721 & 0.36 .53 \\
\hline
\end{tabular}

Dari data daya dan waktu pembakaran maka akan melakukan analisa energi listrik pada tiap sampel yang ada. Berikut merupakan analisa energi listrik menggunakan persamaan

$$
\begin{aligned}
& W=P \cdot t \\
& W=2,64196 \times 1498 \\
& W=3957,66 \mathrm{~J}
\end{aligned}
$$

Tabel 6

Hasil analisa energi listrik

\begin{tabular}{|c|c|c|c|c|c|c|}
\hline \multirow{2}{*}{$\begin{array}{c}\text { Jendis } \\
\text { konsentrasi }\end{array}$} & \multicolumn{2}{|c|}{ Sagu } & \multicolumn{2}{c|}{ Kanji } & \multicolumn{2}{c|}{ Tanah Liat } \\
\cline { 2 - 7 } & $Q$ & $W$ & $Q$ & $W$ & $Q$ & $W$ \\
\hline $\begin{array}{l}\text { Pinus 70\% dant } \\
\text { hatu bara 30\% }\end{array}$ & $3944.16 \mathrm{~J}$ & $3957.66 \mathrm{~J}$ & $4189.32 \mathrm{~J}$ & $4178.56 \mathrm{~J}$ & $3457.44 \mathrm{~J}$ & $3486.33 \mathrm{~J}$ \\
\hline $\begin{array}{l}\text { Pinus 50\% dant } \\
\text { hatu bara 50\% }\end{array}$ & $4533.48 \mathrm{~J}$ & $4432.16 \mathrm{~J}$ & $4230 \mathrm{~J}$ & $4210.11 \mathrm{~J}$ & $4140 \mathrm{~J}$ & $4136.84 \mathrm{~J}$ \\
\hline $\begin{array}{l}\text { Pinus 30\% dant } \\
\text { hatu bara 70\% }\end{array}$ & $4339.98 \mathrm{~J}$ & $4349.4 \mathrm{~J}$ & $4507.02 \mathrm{~J}$ & $4505.74 \mathrm{~J}$ & $4286.52 \mathrm{~J}$ & $4264.92 \mathrm{~J}$ \\
\hline
\end{tabular}

Dari hasil analisa data dapat disimpulkan bahwa nilai energi listrik yang didapatkan hasilnya tidak jauh berbeda dengan hasil analisa kalor. Nilai energi listrik yang didapatkan hingga mencapai $4500 \mathrm{~J}$.

\section{KESIMPULAN}

Berdasarkan hasil penelitian yang telah dilakukan, maka dapat diambil beberapa kesimpulan :

1. Briket dapat dikatakan baik jika memiliki nilai kadar air dibawah $8 \%$ menurut SNI. Dimana kadar air pada perekat sagu diantara kisaran $6 \%$ lebih, sedangkan untuk perekat kanji kisaran 5\%-6\% dan untuk perekat tanah liat mendapatkan nilai kisaran 5\%-7\%.

2. Kadar abu pada penelitian ini sudah memenuhi standar SNI yaitu dibawah $8 \%$, tetapi pada perekat tanah liat memiliki kadar abu yang mendekati $8 \%$ yaitu sebesar $7,95 \%$.

3. Nilai tegangan dan arus dipengaruhi oleh komposisi sampel, dimana semakin kecil persentase kadar daun pinusnya maka semakin kecil, begitu juga sebaliknya.

4. Nilai kalor didapatkan dari hasil analisa data yang ada hingga mendapatkan nilai kalor yang cukup besar yaitu kisaran nilai $4500 \mathrm{~J}$.

5. Penggunaan batu bara muda pada penelitian ini disebabkan karena lebih mudah untuk ditemukan, sedangkan jika menggunakan batu bara tua akan lebih sulit untuk mendapatkannya, yang biasanya hanya terdapat di area pertambangan.

\section{REFERENSI}

[1] Addina, K. N., and Lazulva. "Potential of Bio-briquette of Pineapple Crown Waste (Ananas comosus (L.)" Indonesian Journal of Chemical Science and Technology (IJCST) 2.1(2018): 84-89.s

[2] Amin, A. Z., Pramono, and Sunyoto. "Pengaruh Variasi Jumlah Perekat Tepung Tapioka terhadap Karakteristik Briket Arang Tempurung Kelapa." Sainteknol: Jurnal Sains dan Teknologi 15.2 (2017): 111-118.

[3] Anizar, Heny, Evi S., and Sonia S. "Pengaruh Bahan Perekat Tapioaka Dan Sagu Terhadap Kualitas Briket Arang Kulit Buah Nipah." Perennial 16.1 (2020): 11-17.

[4] Barus, Kasta Efrata, Achwil Putra Munir, and Sulastri Panggabean. "Pembuatan Briket Dari Sekam Padi Dengan Kombinasi Batubara" (Briquetting of Rice Husk With a Combination of Coal)." Jurnal Rekayasa Pangan dan Pertanian 5.2(2017):397-401.

[5] Dwiga, Rahman Syarif. Studi Karakteristik Konversi Energi Panas Menjadi Energi Listrik Menggunakan Termoelektrik Dengan Larutan Urea Sebagai Media Penyimpan Energi Panas. Diss. Universitas Andalas, 2017. Ependi, Selamat. "Pengembangan Perangkat Konversi Energi Panas Menjadi Energi Listrik." (2016).

[6] Hiendro, A., \& Suryadi, D. Perancangan Dan Pengujian Sistem Pembangkit Listrik Berbasis Termoelektrik Dengan Menggunakan Kompor Surya Sebagai Media Pemusat PANAS. Jurnal Teknik Elektro Universitas Tanjungpura,(2019) 2(1).

[7] Jahiding, M., E. S. Hasan, and A. S. Gangganora. "Pengembangan Briket Batubara Muda (Brown Coal) Sebagai Bahan Bakar Alternatif Berkalori Tinggi." Jurnal Aplikasi Fisika 10.1 (2016).

[8] Kunlestiowati, H. "Analisis penyimpangan konversi energi listrik menjadi kalor pada perangkat eksperimen Hukum Joule." JRKPF UAD 5.1 (2018): 34-39

[9] Ningsih, E., Mirzayanti, Y. W., Himawan, H. S., \& Indriani, H. M. (2016). Pengaruh Jenis Perekat pada Briket dari Kulit Buah Bintaro terhadap Waktu Bakar. In Seminar Nasional Teknik Kimia Kejuangan (p. 3).

[10] Mirnawati, M. (2012). Pengaruh konsentrasi Perekat Getah Pinus terhadap Nilai Kalor Pembakaran Biobriket Campuran Sekam Padi dengan Tempurung Kelapa (Doctoral dissertation, Universitas Islam Negeri Alauddin Makassar).

[11] Putra, F. R. J. (2019). Penyimpanan Energi Listrik Dari Konversi Energi Panas Menjadi Energi Listrik Menggunakan Thermoelectric Generator.

[12] Puspita, S. C., Sunarno, H., \& Indarto, B. (2017). Generator termoelektrik untuk pengisisan aki. JFA (Jurnal Fisika dan Aplikasinya), 13(2), 84-87.

[13] Putri, R. E., \& Andasuryani, A. (2017). Studi Mutu Briket Arang Dengan Bahan Baku Limbah Biomassa. Jurnal Teknologi Pertanian Andalas, 21(2), 143- 151.

[14] Rhaharjo, A. C. (2019). Pemanfaatan Limbah Batang Singkong Dengan Penambahan Batubara Sebagai Briket Menggunakan Perekat Tapioka.

[15] Suluh, S. (2019). Studi Eksperimen Pemanfaatan Limbah Daun Bambu, Daun Kopi Dan Daun Pinus Sebagai Bahan Bakar Alternatif. Mechanical Engineering Science (MES), $1(1), 18-23$. 